\title{
IL-1 $\beta$ promotes proliferation and migration of gallbladder cancer cells via Twist activation
}

\author{
RUNSHENG GUO $^{1 *}$, YIYU QIN $^{2 *}$, PEIDONG SHI $^{1}$, JINBI XIE $^{3}$, MING CHOU $^{4}$ and YUEYU CHEN ${ }^{1}$ \\ ${ }^{1}$ Department of General Surgery, Jiading Central Hospital, Shanghai 201800; ${ }^{2}$ Clinical College, \\ Yancheng Institute of Health Sciences, Yancheng, Jiangsu 200137; ${ }^{3}$ Department of Gastroenterology, Jiading Central Hospital, \\ Shanghai 201899; ${ }^{4}$ Department of General Surgery, Changzheng Hospital, Second Military Medical University, \\ Shanghai 201705, P.R. China
}

Received April 12, 2015; Accepted July 20, 2016

DOI: $10.3892 / 01.2016 .5254$

\begin{abstract}
Increasing evidence has revealed a correlation between chronic inflammation and gallbladder cancer (GBC). However, the underlying molecular mechanisms remain to be elucidated. In the present study, secretion of interleukin (IL)-1 $\beta$ was examined in tissues of GBC, chronic cholecystitis and normal gallbladder, as well as in the supernatant of GBC-SD, SGC996 and HIBEpiC cells. The effect of IL-1 $\beta$ on the proliferation and migration of GBC cell lines was also evaluated. In addition, the role of Twist in IL-1 $\beta$-induced proliferation of GBC cells was also studied. It was observed that the level of IL-1 $\beta$ protein in normal gallbladder tissue was low, while it was significantly increased in GBC and chronic cholecystitis tissues. The level of IL- $1 \beta$ protein and mRNA in GBC-SD and SGC996 cells was markedly higher than those in HIBEpiC cells. Exogenous IL-1 $\beta$ promoted the proliferation of GBC-SD and SGC996 cells in vitro and in vivo, and also promoted migration in vitro. The level of Twist protein was significantly increased following treatment with exogenous IL-1 $\beta$. In addition, gene silencing of Twist blocked IL-1 $\beta$-induced proliferation and migration of GBC-SD and SGC996 cells. Taken together, these results indicate that IL-1 $\beta$ promotes proliferation and migration of GBC cells via Twist activation.
\end{abstract}

\section{Introduction}

Primary gallbladder cancer (GBC), though generally considered rare, is the most common malignancy of the biliary

Correspondence to: Dr Yiyu Qin, Clinical College, Yancheng Institute of Health Sciences, 263 South Jiefang Road, Yancheng, Jiangsu 200137, P.R. China

E-mail: qyy128@163.com

Dr Yueyu Chen, Department of General Surgery, Jiading Central Hospital, 1 North Chengbei Road, Shanghai 201800, P.R. China E-mail: cyycx0264@163.com

*Contributed equally

Key words: interleukin-1 $\beta$, Twist, gallbladder cancer tract, ranking fifth in all types of tumors (1). Risk factors for GBC are manifold and include ethnic background, region, age and genetics (2). For the previous few years, epidemiological studies have revealed that an increased frequency of GBC occurs in northern India, Pakistan and Korea $(3,4)$. Therefore, increased attention should be given to GBC in these regions.

Due to vague and nonspecific symptoms during the early stages, the majority of GBC patients present with advanced disease at the time of initial diagnosis (5). The overall mean survival time for patients with GBC is just 6 months, with a 5-year survival rate of $5 \%$ (6). In addition, $\sim 50 \%$ patients succumb to disease within 1 year of diagnosis (6). To date, surgical resection has been the mainstay of therapy for GBC (1). Although reports have demonstrated an increase in survival time for patients who undergo surgical resection, only $20 \sim 30 \%$ of patients are considered as suitable candidates for surgery (1). However, the patients who underwent radical resections do not demonstrated significant differences in 5-year survival rates (5,7). Chemotherapy and radiation, the main adjunctive therapies for surgical resection, have demonstrated no statistically significant benefit for the treatment of advanced GBC (8).

Due to only a small number of studies investigating pathogenesis (9), our knowledge of GBC holds back progress in the treatment of this tumor. It is now widely accepted that the majority of tumors are linked to chronic inflammatory states, particularly certain epithelial tumors (10). Inflammatory mediators, including cytokines, chemokines, nitrogen species and free radicals may act as contributing factors during the process of GBC (2). Chronic exposure to these mediators leads to release of growth factors by tumor cells themselves, which results in the development and progression of cancer (10). For example, IL-8 is able to provoke tumor cell proliferation by activating downstream signals of epidermal growth factor receptor, and regulate tumor metastasis through the cyclin D1 signaling pathway $(11,12)$. Although direct association between chronic cholecystitis and GBC has been observed (13), the underlying molecular mechanism remains to be elucidated.

The present study reports a promoting role of exogenous IL-1 $\beta$ on the proliferation and migration of GBC cell lines GBC-SD and SGC996. Additional investigation identified that promotion depends on Twist, suggesting Twist may have a critical role in IL-1 $\beta$ associated gallbladder carcinogenesis. 
Taken together, the results of the present study reveal that inflammatory mediators have a specific link to GBC.

\section{Materials and methods}

Cell culture and treatment. The GBC-SD GBC cell line was obtained from the China Center for Type Culture Collection (Wuhan University, Wuhan, China). The SGC996 cell line was provided by Tongji University School of Medicine (Shanghai, China). The HIBEpiC cell line was purchased from Sciencell Research Laboratories (Carlsbad, CA, USA). GBC-SD and SGC996 cells were maintained at $37^{\circ} \mathrm{C}$ in Dulbecco's modified Eagle's medium (DMEM; Gibco; Thermo Fisher Scientific, Inc., Waltham, MA, USA) supplemented with $10 \%$ fetal bovine serum (FBS; GE Healthcare Life Sciences, Logan, UT, USA), $1 \mathrm{mM}$ non-essential amino acid (Sigma-Aldrich; EMD Millipore, Billerica, MA, USA) and $1 \%$ penicillin/streptomycin (Gibco; Thermo Fisher Scientific, Inc.) in a $5 \% \mathrm{CO}_{2}$ incubator. HIBEpiC cells were cultured in RPMI-1640 (Gibco; Thermo Fisher Scientific, Inc.). Stock cultures were maintained at $80 \%$ confluence and passaged in $0.25 \%$ trypsin (Gibco; Thermo Fisher Scientific, Inc.) and $1 \%$ ethylenediaminetetraacetic acid in $\mathrm{Ca}^{2+}$ - and $\mathrm{Mg}^{2+}$-free phosphate-buffered saline (PBS). Experimental cells were subcultured in 25 or $75 \mathrm{~cm}^{2}$ flasks overnight at $37^{\circ} \mathrm{C}$.

Lentiviral transfection. To produce cells deficient in Twist, Lenti-Twist-small hairpin RNA (shRNA) (Santa Cruz Biotechnology, Inc., Dallas, TX, USA) was applied. In brief, GBC-SD and SGCC996 cell lines were cultured in 12-well plates for $24 \mathrm{~h}$ at $37^{\circ} \mathrm{C}$, then $5 \mu \mathrm{g} / \mathrm{ml}$ Lenti-Twist-shRNA or Lenti-control was added. Following $24 \mathrm{~h}$ of transfection at $37^{\circ} \mathrm{C}$, cells were cultured in complete media overnight at $37^{\circ} \mathrm{C}$. To screen out stable transfected cells lines, cells were subcultured in $25 \mathrm{~cm}^{2}$ flasks with $5 \mu \mathrm{g} / \mathrm{ml}$ puromycin for $24-48 \mathrm{~h}$ at $37^{\circ} \mathrm{C}$.

Patient samples. A total of 24 GBC samples were collected from patients at the Department of General Surgery, Changzheng Hospital, Second Military Medical University (Shanghai, China) between January 2005 and January 2012. In the same period, 30 cases of chronic cholecystitis specimens were collected from patients who underwent cholecystectomy, and 8 normal gallbladder samples were collected from patients who underwent the Whipple procedure as the control group. All samples were stored at $-70^{\circ} \mathrm{C}$ immediately following resection until performance of subsequent enzyme-linked immunosorbent assay (ELISA) experiments. Permission was granted by the Ethical Committee of Changzheng Hospital, Second Military Medical University to take biopsies from patients with GBC or chronic cholecystitis. All patients consented to participate in the present study.

Cell proliferation assays. Proliferation of cells cultured in the presence or absence of exogenous IL-1 $\beta$ was measured using the water-soluble tetrazolium salts (WST)-1 cell proliferation assay (Roche Diagnostics GmbH, Mannheim, Germany). A total of $2 \times 10^{5}$ cells per well were seeded into a 96 -well microplate. Exogenous IL-1 $\beta$ was added to the wells of the microplates at the following concentrations: $0,1.25,2.5,5$, $10,20,40,80$ and $160 \mathrm{ng} / \mathrm{ml}$, and incubated for $72 \mathrm{~h}$ at $37^{\circ} \mathrm{C}$.
Following aspiration of the growth medium, the cells were washed once with $100 \mu \mathrm{l}$ of PBS. DMEM (100 $\mu \mathrm{l})$ containing $10 \%$ FBS was placed into the wells, followed by $10 \mu \mathrm{l}$ of WST-1 reagent. The cells were cultured in a $\mathrm{CO}_{2}$ incubator at $37^{\circ} \mathrm{C}$ for $1 \mathrm{~h}$, and the absorbance at $450 \mathrm{~nm}$, minus the absorbance at $630 \mathrm{~nm}$, was measured for each well using a microplate reader.

Mouse xenografts. A total of 36 four-week-old immunodeficient nude female mice were purchased from Shanghai Laboratory Animal Center, Co., Ltd. (Shanghai, China). The mice were housed in a specific pathogen-free environment, where temperature and humidity were maintained at $21^{\circ} \mathrm{C}$ and $55 \%$, respectively. Standard food and water were available ad libitum. GBC-SD and SGC996 cells ( $1 \times 10^{7}$ cells per mouse) were injected subcutaneously into the right flanks of the mice (12 mice per group). When tumors reached a volume of $\sim 0.3 \mathrm{~cm}^{3}$, the mice were randomized into two groups and injected intratumorally with 200 ng IL-1 $\beta$ or PBS every two days for a 5-week period. Tumor formation was monitored twice a week, and tumor volume based on caliper measurements was calculated by the modified ellipsoidal formula [tumor volume $=1 / 2\left(\right.$ length $\mathrm{x}$ width $\left.\left.{ }^{2}\right)\right]$. All animal procedures were approved by the Ethical Committee of the Changzheng Hospital, Second Military Medical University, and they were performed in accordance with institutional guidelines.

Cell migration assays. For migration and invasion assays, $5 \times 10^{4}$ cells treated with IL- $1 \beta$ were plated in the top chamber of Transwell inserts (EMD Millipore), with a membrane containing 8-mm diameter pores in $200 \mu \mathrm{l}$ serum-free media, in triplicate. The inserts were subsequently placed into the bottom chamber wells of a 24-well plate containing media, with $10 \%$ FBS as a chemoattractant. Following $24 \mathrm{~h}$ of incubation at $37^{\circ} \mathrm{C}$, cells remaining on the insert's top layers were removed with a cotton swab. Cells on the lower surface of the membrane were fixed in $100 \%$ methanol for $20 \mathrm{~min}$, followed by staining with Giemsa stain. The cell numbers in five random fields (magnification, x200) were counted under a light microscope for each chamber, and the mean value was calculated.

Measuring IL-1 $\beta$ by ELISA. IL-1 $\beta$ secreted by cells or tissues was confirmed by sandwich ELISA (R\&D Systems, Inc., Minneapolis, MN, USA). For detecting IL-1 $\beta$ content secreted by cells, cell culture medium was transferred into a sterile tube and centrifuged for $20 \mathrm{~min}(500 \mathrm{x} \mathrm{g})$ at $4^{\circ} \mathrm{C}$, and the supernatant was carefully collected. For detecting IL-1 $\beta$ content in tissues, $100 \mathrm{mg}$ of tissue was fully homogenized with PBS and protease inhibitors, and subsequently centrifuged at $500 \mathrm{x} g$ for $20 \mathrm{~min}$ at $4^{\circ} \mathrm{C}$; the supernatant was collected for subsequent experiments. All assays were performed according to the manufacturer's protocol. The absorbance of the supernatant was measured at $450 \mathrm{~nm}$ using a microplate reader.

Western blotting. Subconfluent cells were lysed in SDS Lysis Buffer (Beyotime Institute of Biotechnology, Shanghai, China) and the protein concentration was determined by the bicinchoninic acid protein assay (Pierce Biotechnology; Thermo Fisher Scientific, Inc.). A total of $30 \mu \mathrm{g}$ protein samples were separated on a $12 \%$ sodium dodecyl sulfate-polyacrylamide 
gel electrophoresis gel and transferred to a polyvinylidene difluoride membrane (Immobilon-P; EMD Millipore). The membrane was blocked in 5\% nonfat milk (Bio-Rad Laboratories, Inc., Hercules, CA, USA) in Tris-buffered saline and Tween 20 (TBST; $10 \mathrm{mM}$ Tris, $150 \mathrm{mM} \mathrm{NaCl}, \mathrm{pH} 8.0$ and $0.1 \%$ Tween 20) for $1 \mathrm{~h}$ at room temperature. Membranes were probed with anti-Twist (cat. no. sc-134136; 1:1,000; Santa Cruz Biotechnology, Inc.) and anti- $\beta$-actin (cat. no. sc-47778; 1:1,000; Santa Cruz Biotechnology, Inc.) primary antibodies overnight at $4^{\circ} \mathrm{C}$, washed three times in TBST, incubated with horseradish peroxidase-conjugated anti-mouse (cat. no. sc-2005; 1:2,000; Santa Cruz Biotechnology, Inc.) and anti-rabbit (cat. no. sc-2004; $1: 5,000)$ secondary antibodies for $1 \mathrm{~h}$ at $25^{\circ} \mathrm{C}$ and then washed three times in TBST. The signal was visualized using an enhanced chemiluminescence solution (ECL Plus; GE Healthcare Life Sciences, Chalfont, UK) and was exposed to Carestream ${ }^{\circledR}$ Kodak $^{\circledR}$ Co. X-Omat LS film (Sigma-Aldrich; EMD Millipore). Band intensities were quantified using ImageJ 1.11 software (National Institutes of Health, Bethesda, MD, USA).

Reverse transcription-polymerase chain reaction (RT-PCR). Total RNA was isolated using TRIzol reagent (Invitrogen; Thermo Fisher Scientific, Inc.), and RT-PCR was performed using the PrimeScript ${ }^{\mathrm{TM}}$ RT Master Mix for RT-PCR (Invitrogen; Thermo Fisher Scientific, Inc.), according to the manufacturer's protocol. PCR was performed using gene-specific primers, as follows: Twist forward, 5'-TTCAAA GAA ACAGGGCGTGG-3' and reverse, 5'-ATGCCTTTC CTT TCAGTGGC-3'; IL-1 $\beta$ forward, 5'-GGAGAATGACCT GAGCACCT-3' and reverse, 5'-GGAGGTGGAGAGCTTTCA GT-3'; glyceraldehyde-3-phosphate dehydrogenase forward, 5'-CACATCGCTCAGACACCATG-3' and reverse, 5'-TGA CGGTGCCATGGAATTTG-3'. A total of 35 amplification cycles were performed as follows: Denaturation at $94^{\circ} \mathrm{C}$ for $30 \mathrm{sec}$, annealing at $55^{\circ} \mathrm{C}$ for $30 \mathrm{sec}$ and elongation at $72^{\circ} \mathrm{C}$ for $30 \mathrm{sec}$. A final extension step was performed at $72^{\circ} \mathrm{C}$ for $5 \mathrm{~min}$ and then sustained at $4^{\circ} \mathrm{C}$. PCR products were resolved by $2 \%$ agarose gel electrophoresis and stained with ethidium bromide (Sigma-Aldrich; EMD Millipore) for visualization.

Statistical analysis. All experiments reported in the present study were performed independently at least three times and data (expressed as the mean \pm standard deviation) from a representative experiment are shown. Statistical significance was assessed by one-way analysis of variance using SPSS 17.0 software (. $\mathrm{P}<0.05$ was considered to represent a statistically significant difference.

\section{Results}

$I L-1 \beta$ is highly expressed in GBC tissues and cell lines. To investigate the secretion of IL-1 $\beta$ in tissues of GBC, chronic cholecystitis and normal gallbladder, biopsies were obtained from patients and ELISA was performed on these tissue samples. It was observed that the level of IL-1 $\beta$ protein in normal gallbladder tissue was low, while it was significantly increased in GBC and chronic cholecystitis tissues $(\mathrm{P}<0.001$; Fig. 1A). The IL- $1 \beta$ concentration was $422.3 \pm 48.9 \mathrm{ng} / \mathrm{ml}$ in chronic cholecystitis tissue and $616.4 \pm 95.7 \mathrm{ng} / \mathrm{ml}$ in GBC tissue, which
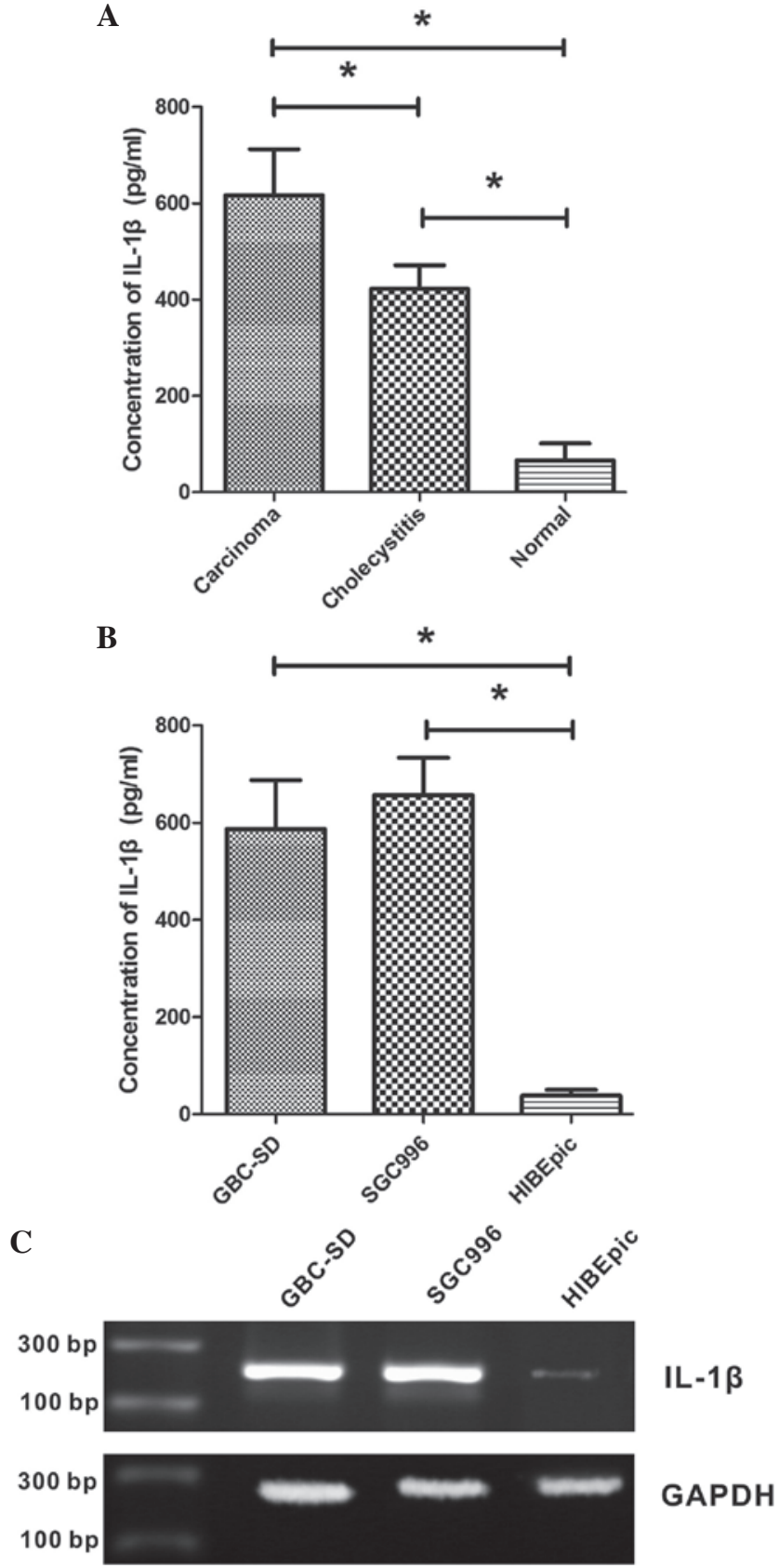

Figure 1. Upregulated secretion of IL-1 $\beta$ in gallbladder tumors and chronic cholecystitis. (A) The representative ELISA displays the comparison between the secretion of IL-1 $\beta$ among the tissues of gallbladder cancer, chronic cholecystitis and normal gallbladder. (B) The IL-1 $\beta$ concentrations were also investigated in the gallbladder cancer cell lines GBC-SD, SGC996 and the non-malignant gallbladder epithelial cell line HIBEpic. (C) Relative expression of IL-1 $\beta$ mRNA in GBC-SD and SGC996 compared to HIBEpic cells. The quantitative data (A and B) presented in the bar graphs were obtained from three independent ELISA experiments. Data are expressed as the mean \pm standard deviation. ${ }^{*} \mathrm{P}<0.001$ compared with normal gallbladder tissues/cells. IL, interleukin; GAPDH, glyceraldehyde-3-phosphate dehydrogenase; ELISA, enzyme-linked immunosorbent assay.

was significantly increased compared with that of the normal gallbladder tissue $(66.4 \pm 35.0 \mathrm{ng} / \mathrm{ml})$. The present study also examined the IL- $1 \beta$ concentrations in GBC cell lines GBC-SD and SGC996, as well as the non-malignant gallbladder epithelial cell line HIBEpiC. As shown in Fig. 1B, GBC cell lines secreted significantly increased levels of IL-1 $\beta$ compared with HIBEpiC cells $(\mathrm{P}<0.001)$. The IL-1 $\beta$ concentrations in the 

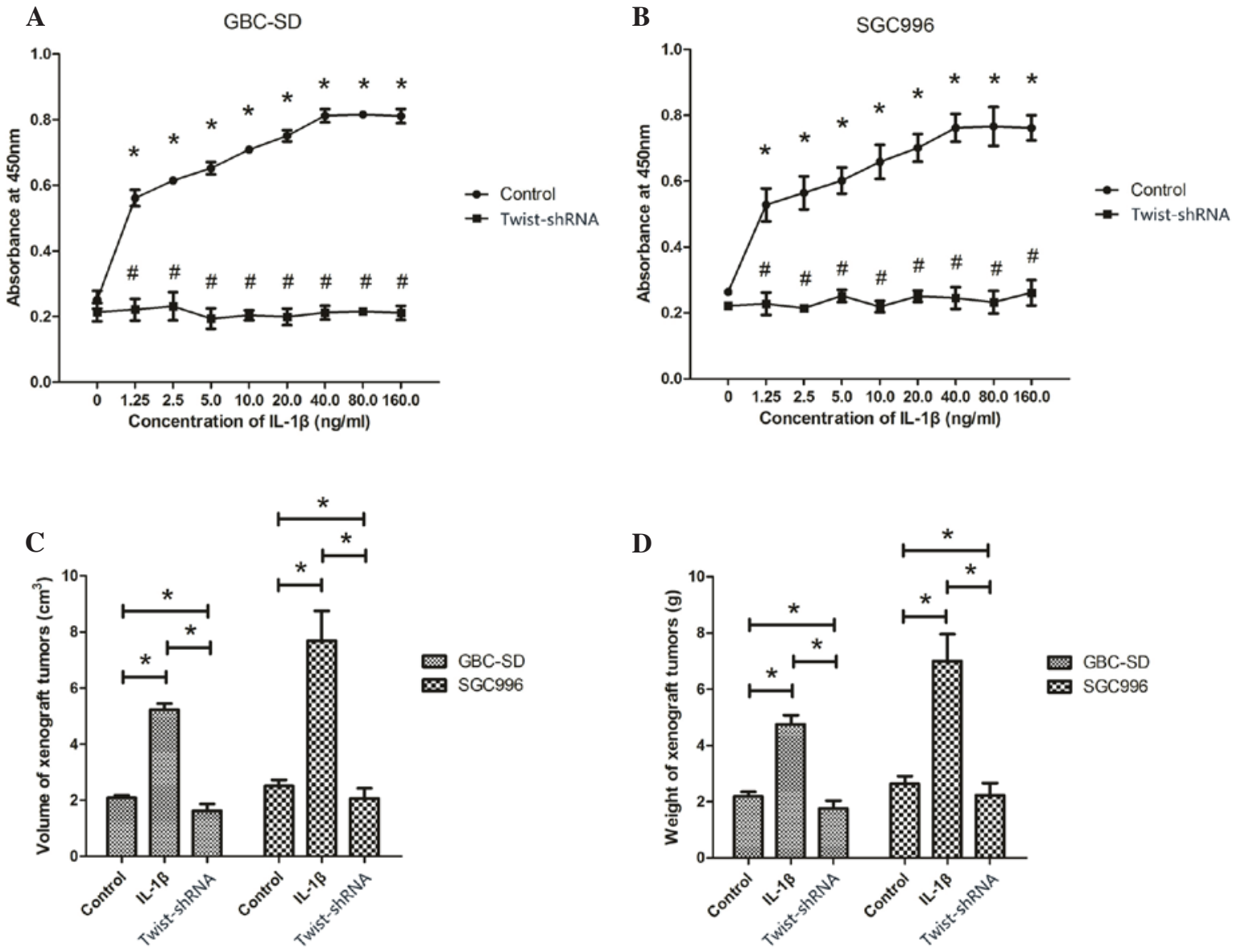

Figure 2. Effect of IL-1 $\beta$ on proliferation of human gallbladder cancer cells in vitro and in vivo. (A) WST-1 assay of GBC-SD cell proliferation changes as a function of IL-1 $\beta$ concentration. (B) WST-1 assay of SGC996 cell proliferation changes as a function of IL-1 $\beta$ concentration. (C) Measurement of tumor volume following tumor injection with or without IL-1 $\beta$. (D) Measurement of tumor weight following tumor injection with or without IL-1 $\beta$. Bar graphs present the data obtained from four independent experiments. All data are expressed as the mean \pm standard deviation. " $\mathrm{P}<0.05$ compared with the control group and each other. IL, interleukin; WST, water-soluble tetrazolium salts; shRNA, small hairpin RNA.

growth medium of GBC-SD, SGC996 and HIBEpiC cells were $587.4 \pm 99.8,657.2 \pm 76.6$ and $38.4 \pm 12.1 \mathrm{ng} / \mathrm{ml}$, respectively.

The expression of IL-1 $\beta$ mRNA in GBC cell lines GBC-SD and SGC996, as well as the non-malignant gallbladder epithelial cell line HIBEpiC, was analyzed using RT-PCR. Expression levels of IL-1 $\beta$ mRNA were increased in GBC cell lines compared with HIBEpiC cells (Fig. 1C).

Exogenous $I L-1 \beta$ promotes the proliferation of $G B C-S D$ and SGC996 cells in vitro and in vivo. To study the effect of IL-1 $\beta$ on proliferation of human GBC cell lines, WST-1 assays were performed to measure the proliferation of GBC-SD and SGC996 cells exposed to $0,1.25,2.5,5,10,20,40,80$ and $160 \mathrm{ng} / \mathrm{ml}$ IL-1 $\beta$. The WST-1 results revealed a concentration-dependent increase in cell proliferation caused by IL-1 $\beta$ $(\mathrm{P}<0.001$; Fig. 2A and B). Between the range of $1.25-40 \mathrm{ng} / \mathrm{ml}$, the proliferation of GBS-SD and SGC996 cells increased along with the concentration of IL-1 $\beta$, while the proliferation of cells did not continue to increase significantly following treatment with 80 and $160 \mathrm{ng} / \mathrm{ml} \mathrm{IL-1} \beta$ ( $\mathrm{P}>0.05$; Fig. $2 \mathrm{~A}$ and B). Therefore, $40 \mathrm{ng} / \mathrm{ml}$, the optimal concentration of IL-1 $\beta$, was used in subsequent experiments. The treatment of the cells with shRNA targeting Twist significantly decreased the proliferation-promoting effect of IL- $1 \beta$.
To investigate whether IL-1 $\beta$ promotes tumor growth in vivo, $\mathrm{GBC}$ xenograft tumor models were established by subcutaneous injection of GBS-SD or SGC996 cells into the flanks of immunodeficient nude mice. Following tumor formation, the mice were randomized into two groups and injected intratumorally with $200 \mathrm{ng}$ IL-1 $\beta$. As shown in Fig. $2 \mathrm{C}$ and $\mathrm{D}$, tumor injection with IL-1 $\beta$ induced a significant increase in tumor growth compared to tumors without IL-1 $\beta$ injection $(\mathrm{P}<0.05)$. However, following Twist silencing, the volume and weight of tumors injected with IL-1 $\beta$ was significantly reduced compared with those not injected with $\operatorname{IL}-1 \beta(\mathrm{P}<0.05)$.

Exogenous IL-1 $\beta$ promotes the migration of $G B C-S D$ and SGC996 cells. The present study additionally analyzed the effects of IL-1 $\beta$ on the migratory behavior of GBC cell lines. As shown in Fig. 3, cells treated with IL-1 $\beta$ exhibited significantly increased migration capacity compared with those not treated with IL-1 $\beta(\mathrm{P}<0.05)$. The number of migrated cells of GBC-SD and SGC996 lines treated with IL-1 $\beta$ was $196.3 \pm 26.1$ and $231.3 \pm 48.2$, respectively, while the number of migrated cells not treated with IL- $1 \beta$ was $92 \pm 12.5$ and

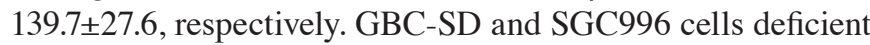
in Twist showed a significant reduction of migration capacity 


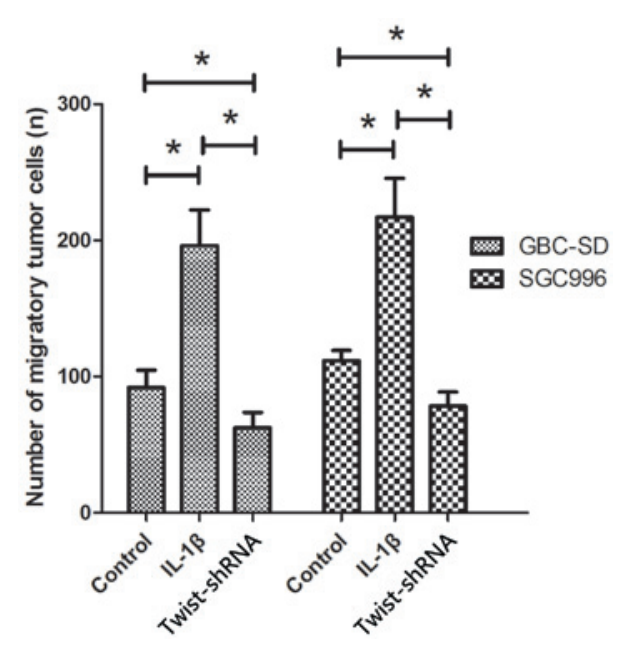

Figure 3. Effect of IL-1 $\beta$ on migration of human gallbladder cancer cells. The mean migrated cell number from three separate experiments. Bar graphs show the mean \pm standard deviation from three independent experiments. ${ }^{*} \mathrm{P}<0.05$ compared to the control group. IL, interleukin; shRNA, small hairpin RNA.

following treatment with IL-1 $\beta$, compared to normal GBC-SD and SGC996 cells $(\mathrm{P}<0.05$; Fig. 3).

$I L-1 \beta$ promotes proliferation and migration of GBC cells via Twist activation. To investigate the potential regulatory pathway of IL-1 $\beta$ in GBC cells, the present study analyzed the effect of IL-1 $\beta$ on the expression of Twist. Western blot analysis was performed to determine the protein level of Twist in GBC cells. GBC-SD and SGC996 cells exposed to IL-1 $\beta$ showed increased protein and mRNA levels of Twist (Fig. 4A and B). Twist-shRNA significantly downregulated the expression of Twist (Fig. 4B and $\mathrm{C}$ ), and downregulation of Twist significantly inhibited the proliferation and migration of GBC-SD and SGC996 cells (Figs. 2 and 3).

\section{Discussion}

IL-1 $\beta$ is a multifunctional and proinflammatory cytokine that has crucial roles in human physiological and pathological activities (14). IL-1 $\beta$, which is widely produced by numerous types of cell, is mainly secreted by immune cells including macrophages and monocytes (15). Furthermore, non-phagocytic cells have also been observed to be involved in secretion of IL-1 $\beta$, including epithelial and tumor cells $(16,17)$. Cells produce and secrete high levels of IL-1 $\beta$ following activation by acute or chronic inflammation or other environmental stimuli; the secretion of IL-1 $\beta$ under normal physiological conditions occurs in a very limited fashion (18). As the core mediator involved in immune regulation and inflammation responses, IL-1 $\beta$ has significant roles in acute and chronic inflammation (19). Previous studies have demonstrated that IL-1 $\beta$ is one of the proinflammatory cytokines released by the tumor microenvironment, and involved in the process of tumor formation (19-24). The aberrant expression of IL-1 $\beta$ is thought to promote tumor growth and metastasis.

However, to the best of our knowledge, an association between IL-1 $\beta$ and GBC has not previously been reported. Previous studies have documented highly constitutive IL-1 $\beta$

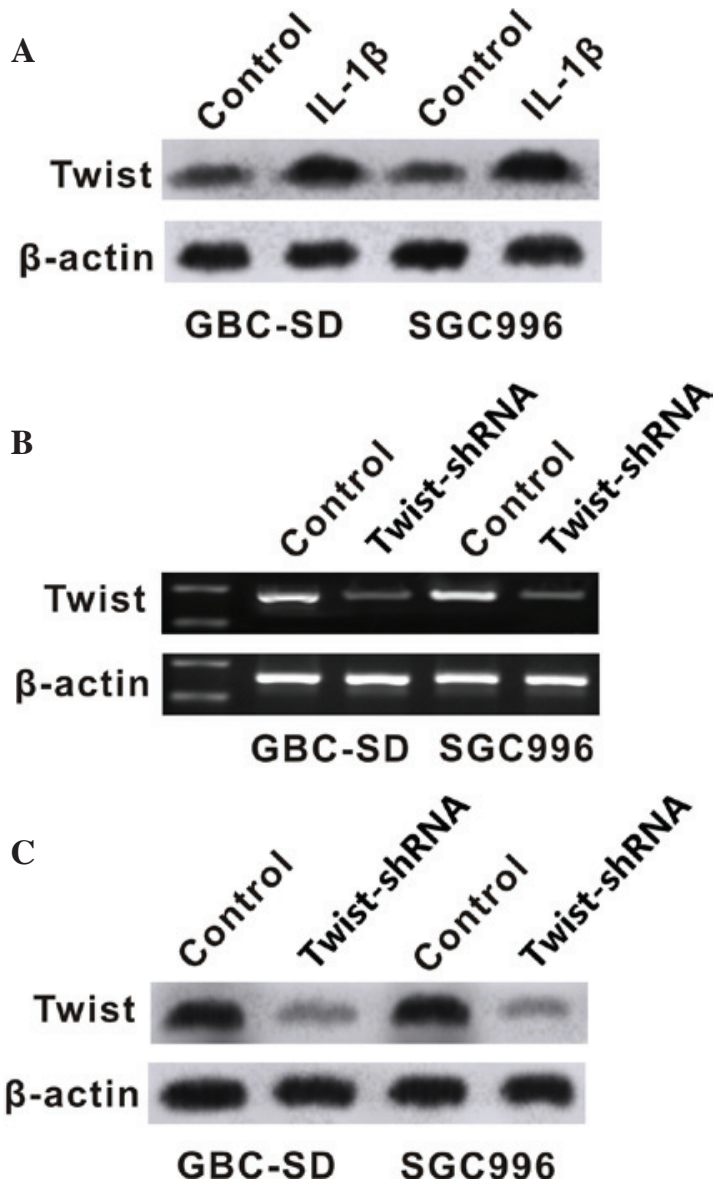

Figure 4. IL-1 $\beta$ increased expression of Twist in gallbladder cancer cell lines. (A) Changes in the Twist protein levels of cells exposed to IL-1 $\beta$ detected by western blotting. (B) Measurement of the Twist mRNA levels of cells treated with Twist-shRNA detected by reverse transcription-polymerase chain reaction. (C) Changes in the Twist protein levels of cells treated with Twist-shRNA detected by western blotting. IL, interleukin; shRNA, small hairpin RNA.

protein production in breast, lung and colon cancer (25-27), which was consistent with the present study, in which IL-1 $\beta$ was upregulated in GBC tissues. The IL-1 $\beta$ expression level was low in normal gallbladder tissue, and was significantly increased in chronic cholecystitis and GBC tissues. These data suggest that IL-1 $\beta$ may participate in the process of chronic cholecystitis and GBC, and its overexpression may contribute to the formation of GBC. The results of the present study also indicate direct evidence of a correlation between chronic cholecystitis and GBC. Additionally, the secretion of IL-1 $\beta$ by GBC cell lines GBC-SD and SGC996 was detected, and the level of secretion was significantly increased compared to the normal gallbladder epithelial cell line HIBEpiC. These results demonstrate that IL-1 $\beta$ secretion is not only induced by inflammation responses, but IL-1 $\beta$ may also be secreted by the gallbladder tumor itself, elevating the overall IL- $1 \beta$ expression.

It is commonly accepted that overexpression of IL- $1 \beta$ promotes tumor growth and metastasis, which is consistent with the results of the present study; exogenous IL- $1 \beta$ promoted the proliferation and migration of GBC cells in vitro and in vivo. Due to its multifunctional role, the underlying mechanism allowing IL-1 $\beta$ to promote tumor growth and metastasis may consist of various signaling pathways, including inducing the 
expression of p38, c-Jun N-terminal kinase, matrix metalloproteinases, vascular endothelial growth factor, basic fibroblast growth factor, IL- 8 and transforming growth factor- $\beta$ that are required for tumorigenesis and metastasis (28-34). Previous studies have reported that IL-1 $\beta$ is able to regulate the epithelial-to-mesenchymal (EMT) transition by activating zinc finger E-box-binding homeobox 1 or stabilizing Snail expression to promote colon cancer formation $(35,36)$.

Twist, another EMT activator, was investigated in the present study. As a basic transcription factor, Twist has been identified as an important factor during the promotion of EMT involved in cancer progression and metastasis (37). Overexpression of Twist has been observed in a number of types of tumor, including lung, stomach, liver, colon, breast and prostate cancer (38-43). In the present study, exposure of GBC-SD and SGC996 cells to IL-1 $\beta$ markedly increased Twist expression, suggesting IL-1 $\beta$ may promote the proliferation of GBC cells via Twist activation. To conform this hypothesis, shRNA was used to knock down the expression of Twist in GBC-SD and SGC996 cells. The results of the present study revealed that gene silencing of Twist blocked IL-1 $\beta$-induced proliferation and migration of GBC-SD and SGC996 cells. Cells deficient in Twist treated with IL-1 $\beta$ exhibited reduced migration capacity compared with normal controls, which may be associated with the inhibition of downstream signaling pathways of Twist. A previous study reported that Twist downregulation may induce migration inhibition and apoptosis (44). Taken together, the results of the present study demonstrated that Twist may act as a key regulation factor participating in IL- $1 \beta$-driven proliferation and migration of GBC cells.

In conclusion, the present study demonstrated that abnormal overexpression of IL- $1 \beta$ contributes to GBC tumorigenesis. IL-1 $\beta$ may promote proliferation and migration of GBC cells via Twist activation. The correlation between chronic inflammation and gallbladder carcinogenesis has been described previously $(45,46)$, although the exact inflammatory mediators involved has yet to be elucidated. To the best of our knowledge, the present study is the first to implicate IL-1 $\beta$ in the tumorigenesis of GBC. Future studies should investigate the molecular mechanisms underlying IL-1 $\beta$-induced proliferation. Particularly, the expression of IL-1R, which acts as the receptor of IL-1 $\beta$, and the downstream regulators, should be examined in GBC.

\section{Acknowledgements}

The present study was supported by the Fund of the Shanghai Institute of Health Sciences (grant no., 2014zr008), Shanghai Municipal Medical Health Cultivation Planning of Outstanding Youth (grant no., AB83190002012023) and Shanghai Medical Key Specialist Construction Plans (grant no., ZK2012A15).

\section{References}

1. Misra S, Chaturvedi A and Misra NC: Gallbladder cancer. Curr Treat Options Gastroenterol 9: 95-106, 2006.

2. Stinton LM and Shaffer EA: Epidemiology of gallbladder disease: Cholelithiasis and cancer. Gut Liver 6: 172-187, 2012.

3. Eslick GD: Epidemiology of gallbladder cancer. Gastroenterol Clin North Am 39: 307-330, 2010.

4. Hundal R and Shaffer EA: Gallbladder cancer: Epidemiology and outcome. Clin Epidemiol 6: 99-109, 2014.
5. Misra S, Chaturvedi A, Misra NC and Sharma ID: Carcinoma of the gallbladder. Lancet Oncol 4: 167-176, 2003.

6. Levy AD, Murakata LA and Rohrmann CA Jr: Gallbladder carcinoma: Radiologic-pathologic correlation. Radiographics 21: 295-314, 2001.

7. Sikora SS and Singh RK: Surgical strategies in patients with gallbladder cancer: Nihilism to optimism. J Surg Oncol 93: 670-681, 2006.

8. Bonet Beltrán M, Allal AS, Gich I, Solé JM and Carrió I: Is adjuvant radiotherapy needed after curative resection of extrahepatic biliary tract cancers? A systematic review with a meta-analysis of observational studies. Cancer Treat Rev 38: 111-119, 2012.

9. Wistuba II, Sugio K, Hung J, Kishimoto Y, Virmani AK, Roa I, Albores-Saavedra J and Gazdar AF: Allele-specific mutations involved in the pathogenesis of endemic gallbladder carcinoma in Chile. Cancer Res 55: 2511-2515, 1995.

10. Landskron G, De la Fuente M, Thuwajit P, Thuwajit C and Hermoso MA: Chronic inflammation and cytokines in the tumor microenvironment. J Immunol Res 2014: 149185, 2014.

11. Singh RK and Lokeshwar BL: The IL-8-regulated chemokine receptor CXCR7 stimulates EGFR signaling to promote prostate cancer growth. Cancer Res 71: 3268-3277, 2011.

12. Bai Z, Tai Y,Li W, Zhen C, Gu W, Jian Z, Wang Q, Lin JE, Zhao Q, Gong W, et al: Gankyrin activates IL-8 to promote hepatic metastasis of colorectal cancer. Cancer Res 73: 4548-4558, 2013.

13. Rashid A, Ueki T, Gao YT, Houlihan PS, Wallace C, Wang BS, Shen MC, Deng J and Hsing AW: K-ras mutation, p53 overexpression, and microsatellite instability in biliary tract cancers: A population-based study in China. Clin Cancer Res 8: 3156-3163, 2002.

14. Wang H, Ding W, Yang D, Gu T, Yang S and Bai Z: Different concentrations of $17 \beta$-estradiol modulates apoptosis induced by interleukin-1 $\beta$ in rat annulus fibrosus cells. Mol Med Rep 10: 2745-2751, 2014.

15. Suzuki H and Ikeda K: Mode of action of long-term low-dose macrolide therapy for chronic sinusitis in the light of neutrophil recruitment. Curr Drug Targets Inflamm Allergy 1: 117-126, 2002.

16. Jiang HY, Wang F, Chen HM and Yan XJ: $\kappa$-carrageenan induces the disruption of intestinal epithelial Caco-2 monolayers by promoting the interaction between intestinal epithelial cells and immune cells. Mol Med Rep 8: 1635-1642, 2013.

17. Giovanni Germano, Paola Allavena and Mantovani A: Cytokines as a key component of cancer-related inflammation. Cytokine 43: 374-379, 2008.

18. Herman AP, Krawczyńska A, Bochenek J, Dobek E, Herman A and Tomaszewska-Zaremba D: LPS-induced inflammation potentiates the IL-1 $\beta$-mediated reduction of $\mathrm{LH}$ secretion from the anterior pituitary explants. Clin Dev Immunol 2013: 926937, 2013.

19. Voronov E, Carmi Y and Apte RN: Role of IL-1-mediated inflammation in tumor angiogenesis. Adv Exp Med Biol 601: 265-270, 2007.

20. Lewis AM, Varghese S, Xu H and Alexander HR: Interleukin-1 and cancer progression: The emerging role of interleukin-1 receptor antagonist as a novel therapeutic agent in cancer treatment. J Transl Med 4: 48, 2006.

21. Tu S, Bhagat G, Cui G, Takaishi S, Kurt-Jones EA, Rickman B, Betz KS, Penz-Oesterreicher M, Bjorkdahl O, Fox JG and Wang TC: Overexpression of interleukin-1beta induces gastric inflammation and cancer and mobilizes myeloid-derived suppressor cells in mice. Cancer Cell 14: 408-419, 2008.

22. Miki C, Konishi N, Ojima E, Hatada T, Inoue Y and Kusunoki M: $\mathrm{C}$-reactive protein as a prognostic variable that reflects uncontrolled up-regulation of the IL-1-IL-6 network system in colorectal carcinoma. Dig Dis Sci 49: 970-976, 2004.

23. Krelin Y, Voronov E, Dotan S, Elkabets M, Reich E, Fogel M, Huszar M, Iwakura Y, Segal S, Dinarello CA and Apte RN: Interleukin-1beta-driven inflammation promotes the development and invasiveness of chemical carcinogen-induced tumors. Cancer Res 67: 1062-1071, 2007.

24. Voronov E, Shouval DS, Krelin Y, Cagnano E, Benharroch D, Iwakura Y, Dinarello CA and Apte RN: IL-1 is required for tumor invasiveness and angiogenesis. Proc Natl Acad Sci USA 100: 2645-2650, 2003.

25. Soria G, Ofri-Shahak M,Haas I, Yaal-Hahoshen N,Leider-Trejo L, Leibovich-Rivkin T, Weitzenfeld P, Meshel T, Shabtai E, Gutman $\mathrm{M}$ and Ben-Baruch A: Inflammatory mediators in breast cancer: Coordinated expression of TNF $\alpha$ \& IL-1 $\beta$ with CCL2 \& CCL5 and effects on epithelial-to-mesenchymal transition. BMC Cancer 11: 130, 2011. 
26. Colasante A, Mascetra N, Brunetti M, Lattanzio G, Diodoro M Caltagirone S, Musiani P and Aiello FB: Transforming growth factor beta 1, interleukin-8 and interleukin-1, in non-small-cell lung tumors. Am J Respir Crit Care Med 156: 968-973, 1997.

27. Apte RN and Voronov E: Interleukin-1 - a major pleiotropic cytokine in tumor-host interactions. Semin Cancer Biol 12: 277-290, 2002.

28. Huang Q, Lan F, Wang X, Yu Y, Ouyang X, Zheng F, Han J, Lin Y, Xie Y, Xie F, et al: IL-1 $\beta$-induced activation of p38 promotes metastasis in gastric adenocarcinoma via upregulation of AP-1/c-fos, MMP2 and MMP9. Mol Cancer 13: 18, 2014.

29. Petrella BL and Vincenti MP: Interleukin-1 $\beta$ mediates metalloproteinase-dependent renal cell carcinoma tumor cell invasion through the activation of CCAAT enhancer binding protein $\beta$. Cancer Med 1: 17-27, 2012.

30. Stetler-Stevenson WG and Yu AE: Proteases in invasion: Matrix metalloproteinases. Semin Cancer Biol 11: 143-152, 2001.

31. Mantovani A and Dejana E: Cytokines as communication signals between leukocytes and endothelial cells. Immunol Today 10 370-375, 1989.

32. Strieter RM, Polverini PJ, Arenberg DA and Kunkel SL: The role of CXC chemokines as regulators of angiogenesis. Shock 4 $155-160,1995$

33. Folkman J and D'Amore PA: Blood vessel formation: What is its molecular basis? Cell 87: 1153-1155, 1996.

34. Dinarello CA: Biologic basis for interleukin-1 in disease Blood 87: 2095-2147, 1996

35. Li Y, Wang L, Pappan L, Galliher-Beckley A and Shi J: IL-1 $\beta$ promotes stemness and invasiveness of colon cancer cells through Zeb1 activation. Mol Cancer 11: 87, 2012.

36. Kaler P, Galea V, Augenlicht L and Klampfer L: Tumor associated macrophages protect colon cancer cells from TRAIL-induced apoptosis through IL-1beta-dependent stabilization of Snail in tumor cells. PLoS One 5: e11700, 2010.
37. Martin A and Cano A: Tumorigenesis: Twist1 links EMT to self-renewal. Nat Cell Biol 12: 924-925, 2010.

38. Li LZ, Zhang CZ, Liu LL, Yi C, Lu SX, Zhou X, Zhang ZJ, Peng YH, Yang YZ and Yun JP: miR-720 inhibits tumor invasion and migration in breast cancer by targeting TWIST1. Carcinogenesis 35: 469-478, 2014.

39. Qian J, Luo Y, Gu X, Zhan W and Wang X: Twist1 promotes gastric cancer cell proliferation through up-regulation of FoxM1. PLoS One 8: e77625, 2013.

40. Chang TM and Hung WC: Transcriptional repression of TWIST1 gene by Prospero-related homeobox 1 inhibits invasiveness of hepatocellular carcinoma cells. FEBS Lett 586: 3746-3752, 2012

41. Chang LH, Chen CH, Huang DY, Pai HC, Pan SL and Teng CM: Thrombin induces expression of twist and cell motility via the hypoxia-inducible factor- $1 \alpha$ translational pathway in colorectal cancer cells. J Cell Physiol 226: 1060-1068, 2011.

42. van Nes JG, de Kruijf EM, Putter H, Faratian D, Munro A, Campbell F, Smit VT, Liefers GJ, Kuppen PJ, van de Velde CJ and Bartlett JM: Co-expression of SNAIL and TWIST determines prognosis in estrogen receptor-positive early breast cancer patients. Breast Cancer Res Treat 133: 49-59, 2012.

43. Gajula RP, Chettiar ST, Williams RD, Thiyagarajan S, Kato Y, Aziz K, Wang R, Gandhi N, Wild AT, Vesuna F, et al: The twist box domain is required for Twist1-induced prostate cancer metastasis. Mol Cancer Res 11: 1387-1400, 2013.

44. Feng MY, Wang K, Song HT, Yu HW, Qin Y, Shi QT and Geng JS: Metastasis-induction and apoptosis-protection by TWIST in gastric cancer cells. Clin Exp Metastasis 26: 1013-1023, 2009 .

45. Espinoza JA, Bizama C, García P, Ferreccio C, Javle M, Miquel JF, Koshiol J and Roa JC: The inflammatory inception of gallbladder cancer. Biochim Biophys Acta 1865: 245-54, 2016.

46. Kumar S, Kumar S and Kumar S: Infection as a risk factor for gallbladder cancer. J Surg Oncol 93: 633-639, 2006. 